\title{
ESENSI TRANSPARANSI DAN AKUNTABILITASI DALAM PENDAFTARAN TANAH DALAM SISTEM HUKUM INDONESIA
}

\author{
Deselfia D.N.M. Sahari \\ Mahasiswa Program Pascasarjana Universitas Muslim Indonesia \\ email : deselfia.sahari@ymail.com
}

\begin{abstract}
The essence of transparency and accountability in land registration within the legal system in Indonesia has not been realized properly. Due to the weakness of the guarantee of legal certainty and legal protection from the government. In addition, the publication system of land registration adopted is negative with a positive tendency, not applied in Article 32 paragraph (2) of Government Regulation Number 24 Year 1997 regarding expiration to file a five-year lawsuit there is a synchronization / non-harmonization concerning land authority between local government Article 14 paragraph (2) Letter $k$ of Law Number 23 Year 2014 regarding Regional Government and Authority of National Land Agency (Regulation of Head of National Land Agency No.2 Year 2013 regarding Abundance of Land Rights and Land Registration Authority) and regulation of grace period of entitlement right.
\end{abstract}

Keywords : Transparency, Accountability, Land Registry, Legal System.

\begin{abstract}
Abstrak
Esensi transparansi dan akuntabilitas dalam pendaftaran tanah dalam sistem hukum di Indonesia belum terealisasi dengan baik. Karena lemahnya jaminan kepastian hukum dan perlindungan hukum dari pemerintah. Selain itu, sistem publikasi pendaftaran tanah yang diadopsi negatif dengan kecenderungan positif, tidak diterapkan dalam Pasal 32 ayat (2) Peraturan Pemerintah Nomor 24 Tahun 1997 tentang berakhirnya pengajuan gugatan lima tahun ada sinkronisasi / non-harmonisasi tentang kewenangan pertanahan antar pemerintah daerah Pasal 14 ayat (2) Huruf k Undang-Undang Nomor 23 Tahun 2014 tentang Pemerintahan Daerah dan Kewenangan Badan Pertanahan Nasional (Peraturan Kepala Badan Pertanahan Nasional No.2 Tahun 2013 tentang Kelimpahan Hak atas Tanah dan Pendaftaran Tanah Otoritas) dan peraturan masa tenggang hak cipta.
\end{abstract}

Kata kunci: Transparansi; Akuntabilitas; Pendaftaran Tanah; Sistem Hukum;

\section{A. PENDAHULUAN}

Pendaftaran tanah merupakan suatu perbuatan administarsi (bestuurs handelingen) berkenaan dengan pencatatan hak-hak atas tanah yang dikuasai atau dimiliki seseorang dan badan hukum. Pencatatan hak-hak atas tanah, dimaksudkan agar setiap bidang-bidang tanah dapat diketahui siapa pemilik, berapa luas, letak, batas-batas serta status hak atas tanah yang telah didaftarkan atau lazim disebut sebagai data fisik dan data yuridis hak atas tanah.

Berkenaan dengan pendaftaran tanah oleh pemegang hak milik, hak guna usaha, Vol. 20 No. 1 Mei 2018 
hak guna bangunan dan pemengang hak-hak lainnya atas tanah, merupakan suatu keharusan bagi pemegang hak.Karena itu, output dari pendaftaran tanah adalah sertifikat hak atas tanah sebagai alat bukti. Hal ini, dimaksudkan supaya ada suatu jaminan perlindungan dan kepastian hukum bagi mereka. Begitu pula halnya yang sudah terdaftar, seharusnya didaftarkan dikantor pertanahan setempat, guna terpeliharanya data fisik dan data yuridis atas bidang tanah, sehingga tercipta tertib administrasi pertanahan yang merupakan salah satu tujuan pendaftaran tanah.

Pendaftaran tanah di Indonesia dapat dilihat dari segi aspek sejarah hukum mulai dari era pra penjajahan dan era penjajahan, setelah kemerdekaan serta lahirnya UUPA. Pendaftaran tanah era pra penjajahan Pada era pra penjajahan di Indonesia tidak ditemukan dokumen sebagai fakta hukum berkenaan dengan penyelanggaraan pendaftaran tanah,Hal ini terjadi, karena pada waktu itu hukum yang berlaku adalah hukum adat yang sebagian besar tidak tertulis. Pada masa penjajahan, hukum yang berlaku di Indonesia bersifat dualisme, yakni berlaku hukum barat bagi golongan Eropa dan Timur Asing serta bagi golongan Bumi Putera yang menundukkan diri pada hukum barat. Disamping itu, berlaku pula hukum adat. Van Vonllenhoven dalam bukunya Adatrecht I telah membagi seluruh daerah Indonesia ke dalam 19 (sembilan belas) lingkaran hukum adat.Tiap-tiap lingkaran hukum adat masing-masing mempunyai sistem pendaftaran tanah yang berbeda dengan hukum adat lainnya, sehigga pada waktu itu, terdapat berbagai sistem pendaftaran tanah di Indonesia, seperti perndaftaran tanah secara sederhana yang di lakukan oleh daerah geran Sultan Deli, geran Lama, geran Kejujuran dan pendaftaran tanah yang ada di Riau, Kepulauan Lingga, Yogyakarta dan Surakarta. Persoalan ini tidak perlu di pertahankan, tetapi segera diadakan penataan kembali guna terciptanya suatu sistem pendaftaran tanah di Indonesia .

\section{B. ANALISIS DAN PEMBAHASAN}

\section{Landasan Teori}

Pada hakikatnya perkataan teori berasal dari kata"theoria" dalam bahasa Latin yang berarti "perenungan" yang pada gilirannya berasal ari kata"thea" dalam bahasa Yunani secara hakiki menyiratkan sesuatu yang disebut dengan "realitas" atau "tontonan". Teori adalah sekumpulan pernyataan-pernyataan yang saling berkaitan dengan suatu fenomena untuk memperoleh suatu kebenaran.

Sementara itu, teori hukum merupakan kelanjutan dari mempejari hukum positif.Setidak-tidaknya dalam urutan yang demikian itulah kita memrekonstruksikan kehadiran teori hukum secara jelas. Pada saat orang mempelajari hukum postif, maka ia sepanjang waktunya di hadapkan pada peraturan-peraturan hukum dengan segala cabang kegiatan dan permasalahannya, seperti halnya kesalahannya, penafsirannya dan sebagainya.

Lebih lanjut Malcolm Waters dikutip H.R. Otje Salman dan Anthon F. Susanto menyatakan bahwa, teori hendaknya meliputi semua perangkat pernyataan yang tersusun dengan sengaja yang dapat memenuhi kriteria sebagai berikut :

a. Pernyataan itu harus abstrak yakni harus dipisahkan dari praktik-praktik sosial yang di lakukan. Teori biasanya mencapai abstraksi melalui pengembangan konsep teknis yang hanya digunakan dalam komunitas tertentu;

b. Pernyataan itu harus tematis. Argumentasi tematis tertentu harus diungkapkan melalui Vol. 20 No. 1 Mei 2018 
seperangkat pernyataan yang menjadikan pernyataan itu koheren dan kuat;

c. Pernyataan itu harus konsisten secara logika. Pernyataan-pernyataan itu tidak boleh saling berlawanan satu sama laian dan jika mungkin dapat ditarik kesimpulan dari satu dan lainnya;

d. Pernyataan itu harus jelas. Teori harus mengungkapkan suatu disertasi atau argumentasi tentang fenomena tertentu yang dapat menerangkan bentuk substansi atau eksistensinya;

e. Pernyataan itu harus umum pada prinsipnya, pernyataan itu harus dapat digunakan dan menerangkan semua atau contoh fenomena apapun yang mereka coba terangkan;

f. Pernyataan-pernyataan itu harus independen. Pernyataan itu tidak boleh dikurangi hingga penjelasan yang ditawarkan para partisipan untuk tingkah laku mereka sendiri;

g. Pernyataan-pernyataan itu harus substansi harus valid. Pernyataan itu harus konsisten tentang apa yang diketahui dunia sosial oleh partisipan dan ahli-ahli lainnya.

Minimal harus ada aturan-aturan penerjemahan yang dapat menghubungkan teori dengan ilmu yang bahkan pengetahuan lainnya. Selanjutnya, tujuan teori hukum menurut Radbruch, bahwa The task legal theory is clarification of legal values and pustulates up to their ultimate philosophical foundation. Beliau beranggapan bahwa kebenaran suatu teori hukum adalah untuk mempelajari nilai-nilai hukum serta postulat-postulatnya sampai pada landasa filosofinya yang mendalam.

Landasan filosofis dari hukum positif yang berlaku di Indonesia, telah termuat dalam sila-sila Pancasila sebagai dasar negara dalam berbangsa dan bernegara. Dengan demikian, untuk mendukung keberhasilan penelitian ini dipergunakan teori-teori hukum yang relevan yaitu :

a) Teori tujuan hukum merupakan salah satu bentuk karya manusia tertentu dalam rangka mengatur kehidupan manusia itu sendiri. Oleh karena itu, kita akan dapat menemukan dalam berbagai bentuk, di antaranya bentuk-bentuk hukum tersebut, yang paling tegas dan terinci mengutarakan isinya adalah dalam bentuk kebiasaan yang diulang-ulang . Kedua jenis hukum dimaksud mempunyai tujuan yang disebut tujuan hukum.

Tujuan hukum memberikan peraturan-peraturan (petunjuk, pedoman) dalam pergaulan hidup, untuk melindungi individu dalam hubungannya dengan masyarakat, sehingga dengan demikian dapat diharapkan terwujudnya suatu keadaan aman, tertib dan adil. Tujuan hukum ialah: mengatur pergaulan hidup secara damai

.hukummenghendaki perdamaian .kemudian memberlakukan hukum sebagai sarana untuk mencapai tujuan ini, karena hukum secara teknik dapat memberikan atau melakukan hal-hal sebagai berikut :

1) Hukum merupakan suatu sarana untuk menjamin kepastian dan memberikan prediktibilitas di dalam kehidupan masyarakat;

2) Hukum merupakan suatu sarana bagi pemerintahan untuk menerapkan sanksi;

3) Hukum sering di pakai oleh pemerintahan sebagai sarana untuk melindungi kritik;

4) Hukum dapat digunakan sebagai sarana untuk mendistribusikan sumber-sumber daya. 
Menurut Gustav Readbruch dengan istilah Tiga Ide Dasar Hukum atau Tiga Nilai Dasar Hukum, itu juga yang disebut sebagai tujuan hukum dalam makna yang luas masing-masing keadilan, kemanfaatan dan kepastian hukum. Lebih lanjut dikatakan, tetapi dari keseluruhan pendapatan tentang apa merupakan tujuan hukum, dapat di klasifikasikannya pada umumnya ke dalam tiga aliran :

1) Aliran etis yang menganggap pada asasnya tujuan hukum adalah untuk mencapai keadilan;

2) Aliran ultitis yang menggangap pada asasnya tujuan hukum adalah untuk menciptakan kemanfaatan;

3) Aliran yuridis-formal yang menganggap pada asasnya tujuan hukum adalah untuk menciptakan kepastian hukum.

Achmad Ali sependapat dengan Gustav Rabdruch yang mengatakan bahwa kita harus menganut asas prioritas, yaitu dalam mewujudkan tujuan hukum, maka dipergunakan skala prioritas, terlebih dahulu diprioritaskan keadilan, kemudian kemanfaatan dan terakhir kepastian hukum. Idealnya memang selalu diupayakan agar setiap aturan hukum dan setiap penerapan atauran hukum senantiasa dapat berhasil mencapai perwujudkan keadilan, kemanfaatan dan kepastian hukum, tetapi jika mungkin, maka skala prioritaslah yang harus diberlakukan.

Berkenaan dengan pendaftaran tanah di Indonesia, maka tujuan pendaftaran tanah dilakukan oleh pemerintah adalah untuk memberikan kepastian hukum dan perlindungan hukum kepada pemegang hak atas suatu bidang tanah, satuan rumah susun dan hak-hak lainnya yang terdaftar, sebagaimana ditegaskan dalam pasal 19 UUPA dan Pasal 3 PP. No. 24 Tahun 1997. Akhirnya apabila bidang-bidang tanah telah didaftar, maka pemegang hak atas tanah akan di berikan berupa sertifikat hak atas tanah sebagai tanda bukti hak.

b) Teori kewenangan oleh Phillipus M Hadjon ditetapkan sebagai middle theory

.wewenang dalam konsep kepustakaan hukum Indonesia adalah merupakan konsep public. Hal ini berbeda dengan konsep hukum Belanda dapat di maknai privatrechtelijk bevoegdheid .berdasarkan konsep wewenang dalam hukum Indonesia , wewenang biasa diperoleh melalui atribusi, delegasi dan mandat yang bersumber dari peraturan perundang-undangan.

Kemudian dalam konsep hukum publik wewenang berkaitan dengan kekuasaan. Lebih lanjut dinyatakan bahwa ada tiga cara atau sumber memperoleh kewenangan, yaitu Atribusi: wewenang yang melekat pada suatu jabatan menurut peraturan perundang-undangan dalam jabatan. Contoh kewenangan Bupati, kewenangan Gubernur. Gelegasi :pelimpahan wewenang, contoh UU No.32 Tahun 2004 tentang Pemerintahan Daerah. Mandat: penugasan pada bawahan berkaitan dengan jabatan.

Delegasi dalam pemberian mandat, pejabat yang diberikan mandat menunjuk pejabat lain untuk bertindak atas nama mandator (pemberi mandat). Jadi kewenangan dimaksud tidak dapat didelegasikan secara besar-besaran,tetapi hanya mungkin apabila diatur secara tegas dalam peraturan. Dari segi "Hukum publik" istilah "delegasi" dapat pula digolongkan menjadi dua jenis , yakni : 
1. Delegasi berarti penyerahan (pengalihan) wewenang public intern (Nasional);

2. Delegasi berarti urusan yang telah diserahi wewenang publik untuk mewakili suatu organisasi penyelesaian masalahhubungan antara Negara (hubungan Hukum Publik Internasional).

Menurut Indroharto terdapat tiga pembagian wewenang pemerintah yakni:

Pertama; wewenang pemerintah yang bersifat terikat, yakni terjadi apabila peraturan dasarnya menentukan kapan dan dalam keadaan yang bagaimana wewenang tersebut dapat digunakan atau peraturan dasarnya sedikit banyak menentukan tentang isi dari keputusan yang harus diambil secara rinci maka wewenang pemerintah secara ini merupakan wewenang yang terikat.

Kedua; wewenang fakultatif, terjadi dalam hal badan atau pejabat tata usaha negara yang bersangkutan tidak wajib menerapkan wewenang atau sedikit banyak masih ada pilihan, sekalipun itu hanya dapat dilakukan dalam hal-hal tertentu atau keadaan-keadaan tertentu sebagaimana di tentukan dalam peraturan dasarnya.

Ketiga; wewenang bebas, yakni terjadi ketika peraturan dasarnya memberikan kebebasan kepada badan atau pejabat tata usaha negara untuk menentukan sendiri isi dari keputusan yang akan di keluarkan atau peraturan dasarnya memberikan ruang lingkup kebebasan kepada pejabat tata usaha yang bersangkutan.

\section{Metode Penelitian}

Adapun tipe penelitian normatif Legal research adalah penelitian yang bersifat deskriptif (desekriptive research) dengan menggunakan pendekatan empiris dan normatif. Diliat dari segi tujuan penelitian ini adalah penelitian problem indetification, yakni peneltitian yang bertujuan mengidentifikasi masalah-masalah yang berkaitan dengan pelaksanaan pendaftaran di Indonesia.

Pengkajian ini dilakukan dalam tiga lapisan hokum, yakni dogmatika hukum,teori hukum dan filsafat hukum. Lapisan ilmu hukum dogmatika hukum dimaksud untuk mengkaji terhadap substansi peraturan perundang-undangan yang terkait dengan pendaftaran tanah. Pada lapisan teori hukum akan dikaji dalam beberapa teori hukum yang berkaitan dengan pendaftaran tanah.

Lapisan filsafat hukum atau pandangan hidup suatu bangsa tiada berisi nilai-nilai atau etika dari bangsa.Hal ini dimaksud untuk mengkaji prinsip-prinsip dasar yang menjadi landasan hukum berkenaan pendaftaran tanah, sehingga peraturan yang disusun tidak terlepas dari konteks keberlakuan secara yuridis, sosiologis dan filosofis.

Penelitian ini akan berlangsung dalam wilayah hukum Provinsi Sulawesi Selatan,d engan berkonsentrasi pada pelaksanaan pendaftaran tanah pada 5 daerah kabupaten/kota. Adapun penelitian lokasi penelitian, meliputi:

1. Kota Makassar

2. Kabupaten Gowa

3. Kabupaten Maros

4. Kabupaten Barru

5. Kota Parepare 
Pertimbangan memilih lokasi penelitian diatas, karena daerah tersebut masingmasing memiliki wilayah daratan berupa tanah darat, sawah tanah perumahan yang luas dan sebagaian besar masih belum di lakukan daftarkan tanah. Oleh karena itu, lokasi penelitian ini di pandang dapat mewakili Provinsi Sulawesi Selatan, megingat keberadaan wilayah lain juga sebagian besar bidang-bidang tanahnya belum di lakukan pendaftaran tanah.

Populasi penelitian adalah warga masyarakat memiliki tanah dan petugas pendaftaran tanah, praktisi hukum dan tokoh masyarakat yang ada dalam lokasi penelitian, karena jumlahnya terlalu besar sehingga dimungkinkan melakukan penarikan samel dalam jumlah yang tertentu dari seluruh populasi sudah cukup repsentatif untuk di teliti. Adapun rincian sampel penelitian sebagai berikut:

a. Petugas pendaftaran tanah sebanyak 20 responden;

b. Pemilik tanah sebanyak 20 responden;

c. Praktisi hukum sebanyak 20 responden;

d. Tokoh dan pemuka masyarakat 20 responden.

Teknik pengumpulan data yaitu:

1. Penelitian kepustakaan, bertujuan mencari dan menemukan teori dan doktrina hukum sebagai dalil-dali ilmiah dengan cara membaca buku literatur, karya ilmiah, dokumentasi, peraturan perundang-undangan,juklak dan juknis pendaftaran tanah.

2. Penelitian lapangan, bertujuan untuk memperoleh informasi dan fakta empiris melalui teknik wawancara, Tanya jawab dan pengedaran kuesioner.

Data kuantitatif di hitung dengan mempergunakan rumus frekuensi sebagai berikut:

$$
\mathrm{P}={ }_{-}^{f} \mathrm{X} 100 \%
$$

Keterangan:

$\mathrm{P}=$ Presentase;

$f=$ frekuensi;

$\mathrm{N}=$ jumlah sampel;

$\%=$ pembulat (Soerjono Soekanto,1996:284).

\section{Faktor Berpengaruh Terhadap Transparansi dan Akuntabilitas Pada Pendaftaran Tanah DalamSistem Hukum Indonesia}

Budaya hukum merupakan elemen penting dalam proses pelaksanaan pendaftaran tanah, tentu saja budaya hukum yang baik, karena budaya hukum merupakan salah satu bagian dari sistem hukum yang sangat menetukan efektivitas penengakan hukum.

Secara harfiah kebudayaan dengan asal kata budaya diartikan sebagai hal-hal yang bersangkutan dengan budi dan akal atau hasil karya, rasa dan cipta manusia. Sehubungan dengan hal tersebut dapat dipahami, bahwa sifat dan hakikat dari budaya itu adalah sikap dan tingkahlaku manusia yang selalu dinamis, bergerak dan beraktivitas untuk mematuhi kebutuhan hidupnya dengan cara melakukan hubunganhubungan dengan manusia lainnya.

Budaya hukum sebagai salah satu instrument yang berpengaruh terhadap Vol. 20 No. 1 Mei 2018 
pelaksanaan pendaftaran tanah.Oleh karena, keberadaan faktor budaya hukum senantiasi bersinergi dengan elemen sikap dan nilai sosial yang merupakan suatu pilihan hukum.

Keberadaan budaya hukum sebagai salah satu variabel dalam penelitian ini, akan diukur sejauh mana pengaruh budaya hukum dalam pelaksanaan pendaftaran tanah. Adapun faktor budaya hukum dimaksud terbatas pada persepsi atau cara pandangan seseorang terhadap sikap atau perilaku, dan mentalitas aparat Kantor Pertanahan Kabupaten/Kota, masyarakat atau pemohon sertifikat hak atas tanah berkenaan dengan pendaftaran tanah.

Berdasarkan hasil penelitian diperoleh data empiris, bahwa pengaruh faktor budaya hukum pegawai kantor BPN Kabupaten/Kota (Makassar, Gowa, Maros, Barru, Pare-Pare) maupun pemilik tanah dan pihak-pihak terkait dapat mempengaruhi pelaksanaan pendaftaran tanah.Hal ini tergambar pada tabel dibawah ini:

\section{Tabel 1} Pengaruh Faktor Budaya Hukum Terhadap Pelaksanaan
Pendaftaran Tanah

\begin{tabular}{|c|c|c|c|}
\hline No & Kategori & Frekuensi & Persentase \\
\hline 1 & $\begin{array}{l}\text { Berpengaruh } \\
\text { Kurang Berpengaruh }\end{array}$ & 41 & 51,25 \\
\hline 2 & Tidak Berpengaruh & 27 & 33,75 \\
\hline 3 & & 12 & 15,00 \\
\hline & Jumlah & 80 & 100,00 \\
\hline
\end{tabular}

Sumber : Data primer setelah diolah tahun 2016.

Berdasarkan data empiris dalam tabel diatas maka diperoleh informasi fenomena yang bersangkutan paut dengan budaya hukum, berpeluang mempengaruhi diri pribadi seseorang, terutama aparat penegak hukum, aparat BPN Kabupaten/Kota dan masyarakat pemilik tanah.

Di antara fenomena-fenomena tersebut terdapat 41 orang responden $(51,25 \%)$ memilih indikator budaya hukum mempengaruhi terhadap pelaksanaan pendaftaran tanah, sementara 27 orang responden $(33,75 \%)$ memilki jawaban budaya hukum kurang berpengaruh tehadap pelaksanaan pendaftaran tanah dan sisanya 12 orang responden (15\%) memilih jawaban budaya hukum tidak berpengaruh terhadap pelaksanaan pendaftaran tanah.

Budaya hukum dalam penelitian ini menjadi penting, karena merupakan salah satu unsur sistem hukum yang menjadi penentu jalannya proses pelaksanaan pendaftaran tanah guna memperoleh sertifikat hak atas tanah. Lebih lanjutnya dikatakan jika hukum dilihat dari pada aspek kulturalnya makan masalahnya akan terumuskan dalam 
beberapa bentuk pertanyaan-pertanyaan tersebut dirumuskan oleh Freidmen sebagai berikut :

a. Pendidikan serta kebiasaan apakah yang dimiliki oleh para pelaksana hukum (law enforcemen);

b. Bagaimana fikiran rakyat terhadap hukum;

c. Apakah golongan atau individu menggunakan secara hukum karena sukarela;

d. Untuk tujuan apakah mereka pergi ke ahli hukum dan untuk tujuan apakah mereka memakai jasa pejabat atau peranta lainnya;

e. Apakah dalam masyarakat terdapat rasa horat terhadap hukum pemerintah atau tradisi;

f. Apakah yang merupakan sumber legitimasi berbagai ketentuan hukum.

Berkaitan dengan hal tersebut di atas maka ketika kita mengaji riwayat kepemilikan tanah yang berdasarkan pada hukum adat maka, pendaftaran kalaupun ada pendaftaran tanah hanya di pergunakan pembayaran pajak. Sikap atau perilaku yang dimaksud dalam penelitian ini adalah tindakan yang didasarkan pada pendirian atau keyakinan aparat kantor pertanahan kabupaten/kota dan masyarakat atau pemohon sertifikat hak atas atas tanah terhadap pelaksanaan pendaftaran tanah. Kategori penelitian dimaksud berkaitan dengan hasil penelitian responden terhadap adanya korelasi antara sikap atau perilaku aparat kantor pertanahan dan masyarakat atau pemohon setifikat atas tanah berkenaan dengan penerbitan hak-hak atas tanah.

\section{C.SIMPULAN}

Esensi transparansi dan akutabilitas dalam pendaftaran tanah dalam sistem hukum di Indonesia karena masyarakat belum memperoleh ketentraman dan keadilan, karena akibat lemahnyajaminan kepstian hukum dan perlindungan hukkum dari pemerintah, tidak diterapkan Pasal 32 ayat (2) PP. 24 Tahun 1997. Disamping itu, Indonesia menganut sistem publikasi pendaftaran tanah yakni sistem negatif bertendensi positif.Terdapat ketidaksinkronan aturan hukum antara UUPA dan PP No. 40 Tahun 1996 berkenaan dengan pendaftaran pembaruan hak guna usaha, hak guna bangunan dan hak pakai. Disamping itu, terdapat pula ketidak sinkronan kewenangan pertanahan sebagai termuat Pasal 14 ayat (2) huruf k UU. No. 12 Tahun 2008 tentang perubahan kedua UU No. 32 Tahun 2004 tentang pemerintahan daerah dengan kewenangan BPN Kabupaten/Kota , sebagaimana termuat pada Peraturan Kepala Badan Pertanahan Nasional Republik Indonesia No.2 Tahun 2013 tentang Perlimpahan Kewenangan Pemberian Hak Atas Tanah dan Kegiatan Pndaftaran Tanah. Faktor-faktor yang mempengaruhi pelaksanaan pendaftaran tanah di Indonesia adalah budaya hukum, kesadaran hukum, kemampuan sumber daya manusia dan fasilitas. Berdasarkan data empiris : budaya hukum, masih ditemukan nilai-nilai dan sikap yang kurang positif baik dari aparat pelaksana pendaftaran tanah. Kesadaran hukum masyarakat untuk melakukan pendaftaran tanah masih kurang.Hal ini dapat dilihat dari jumlah tanah yang terdaftar. Sumber daya manusia (SDM) masih kurang khususnya tenaga profesional yang terkait dengan pelaksanaan pendaftaran tanah. Kemudian sarana dan fasilitas, masih kurang atau memadai guna mempercepat terwujudnya pelaksanaan pendaftaran tanah di Indonesia. 


\section{DAFTAR PUSTAKA}

Abdurrahman, 1983.Aneka Masalah Hukum Agraria Dalam Pembangunan Di Indonesia; Seri Hukum Agraria Bandung, Alumni. ,1991. Beberapa Aspekta tentang Hukum Agraria; SeriHukum Agraria V.

Bandung, Alumni.

Achmad Ali, 1990. Mengembara di Belantara Hukum. Ujung Pandang, Lembaga Penerbitan Universitas Hasanuddin.

,1996.Menguak Tabir Hukum. (Suatu Kajian Filosofis dan Sosiologis). Jakarta, Chandra Pratama. ,1998. Mempelajari Kajian Empiris Terhadap Hukum. Jakarta, Watangpone.

, 2009. Menguak Teori Hukum (Legal Theory) dan Teori Peradilan (Judicialprudence) Termasuk Interpretasi Undang-Undang (Legisprudence). Jakarta, Prenada Media Group.

1998.Perubahan Masvarakat Perubahan Hukum dan Penegakan Hukum oleh Hakim. Makassar, Universitas.

Achmad All dan Wiwie Haryani, 2012.Menjelajahi Kajian Empiris Terhadap Hukum.

Jakarta, Prenada Media Group.Hasanuddin.

Adijani Al-Alabij, 1989, Perwakafan Tanah Di Indonesia Dalam teori dan Praktek, Jakarta, Rajawali

Adrian Sutedi, 2007. Perailhan Hair Atas Tanah Dan Pendaftaran.Jakarta, Sinar Grafika.

A.P. Parlindungan, 2004. Pendaftaran Tanah di Indonesia. Bandung, Mandar Maju 1989, Hak Pengelolaan Menurut Sistem UUPA.Bandung, Mandar Maju.

A. Hamid. S. Attamimi, 1993, Hukum Tentang Peraturan PerundangUndangan dan Peraturan Kebijakan, Jakarta, Fakultas Hukum UI,

Alfred Stepen dan Cindy Skach. 1994. Presidentialism and Parliamentarism in Comparative Presvective. London, Baltimore University Press.

Algra, N.E dan K. Van Duyvendijk, 1983.Mula Hukum; Beberapa Bab Mengenai Hukum dan Ilmu untuk Pendidikan Hukum dalam Pengantar Ilmu Hukum.Diterjemahkan oleh J.C.T. Simorangkir dan H. Boerhanoeddin Soetan Batoeah. Bandung, Binacipta.

Alvin S. Johson, 2004. Sosiology Of Law. Diterjemahkan Rinaldi Simanorang, Jakarta, Rineka.

Amier Syarifuddin, 1990. Falsafah Hukum. Bahan Kuliah Program, Pascasarjana UNHAS, Ujung Pandang. 
Anton Moeliono, M, 1988. Kamus Besar Bahasa Indonesia.Jakarta, Departemen Pendidikan dan Kebudayaan Republik indonesia.

Arie Sukanti Hutagalung, 1985. Program Redistribusi Tanah di Indonesia; Suatu Sarana Ke Arah Pemecahan Masalah Penguasaan Tanah dan Pemilikan Tanah.Jakarta, Rajawali Press.

Arie S. Hutagalung,1998, Condominum dan Permasalahannya, Badan, Jakarta, Fakultas Hukum Universitas Indonesia.

Arief Sidharta, 2011. Refleksi Tentang Hukum Pengertian-Pengertian Dasar Dalam Teori Hukum. Bandung, Citra Aditya Bakti.

A.S. Homby E.V. Gatenby and H. Wakefeeld, 1972.The Advance Learners .Dictionary Of Current.

Ateng Syafruddin, 2011. Menuju Pemerintahan Negara Yang Bersih Dan Bertanggung Jawab.Internet.

Bambang Sunggono, 1994. Hukum dan Kebijaksanaan Publik.Jakarta,, Sinar Grafika. ,2005. Metodologi Penelitian Hukum. Jakarta, Raja GrafindoPersada.

Bismar Siregar, 1996. Keadilan Hukum Dalam Berbagai Aspek Hukum Nasional.Jakarta, Rajawali Press.

Bruggink.J.J.H. 1999.Refleksi Tentang Hukum.alih bahasa oleh Arief Sidharta. Bandung, Citra Aditya Bakti.

Boedi Harsono, 1962. Undang-undang Pokok Agraria Sejarah Penyusunan Isi dan Pelaksanaannya.Jakarta, Djambatan. ,1996.Hukum Agraria Indonesia; Himpunan Peraturanperaturan Hukum Tanah.Jakarta, Djambatan.

Burkens, C.M., 1990.Beginselen van de Democratische Rechtssaat.W.E.J, Tjeenk Willink Zwolle.

Brahmana Adhie dan Hasan Basri Nata Menggala, 2001.Reformasi Pertanahan.Bandung, Mandar Maju.

Carl J. Frederich, 1963. Man hisGovernment, An Empirical Theory ofPolitics. New York, me Graw Hill Book Coy.

Pransisto, J. 2018. Analisis Yuridis Tentang Kedudukan Sertifikat Hak Milik Atas Tanah Sebagai Obyek Sengketa Tata Usaha Negara Di Pengadilan Tata Usaha Negara Makassar. PLENO JURE, 7(2), 51-65. 